\title{
Benign fibrous histiocytoma of the maxillary posterior tooth region
}

\author{
Durga Shankar Gupta, ${ }^{1}$ Swapnil S Bumb, ${ }^{2}$ Ankit Jain, ${ }^{1}$ Tarique Ansari ${ }^{1}$
}

${ }^{1}$ Department of Oral and Maxillofacial Surgery,

Teerthanker Mahaveer Dental College and Research Centre, Moradabad, Uttar Pradesh, India

${ }^{2}$ Department of Public Health Dentistry, Teerthanker Mahaveer Dental College and Research Centre, Moradabad, Uttar Pradesh, India

\section{Correspondence to} Dr Swapnil S Bumb, drswapnilbumb@gmail.com

Accepted 15 March 2014

\section{(a) CrossMark}

To cite: Gupta DS, Bumb SS, Jain A, et al. BMJ Case Rep Published online: [please include Day Month Year] doi:10.1136/bcr-2014203934

\section{DESCRIPTION}

Benign fibrous histiocytoma (BFH) is tumour consisting of a mixture of fibroblastic and histiocytic cells. ${ }^{1}$ The occurrence of BFH in the head and neck region, especially in the oral cavity, has been rarely reported. ${ }^{2}$

A 19-year-old woman presented with complaints of pain and swelling on the right side of the face. Intra-oral examination disclosed a nodular and sessile mass measuring $4.0 \times 3.5 \times 3.0 \mathrm{~cm}$ in the right maxillary posterior tooth region (figure 1 ). The lesion was not painful on palpation and was clinically suspected to be a soft tissue fibrosis. Radiographic examination (figure 2) revealed the presence of an impacted right side third molar and the surrounding tooth, involving the maxillary tuberosity. After routine haematological investigation, surgical excision of the lesion was carried out under local anaesthesia in aseptic conditions. The wound was closed with 3-0 silk suture. Postoperatively, an antibiotic, an analgesic and chlorhexidine gluconate mouthwash were

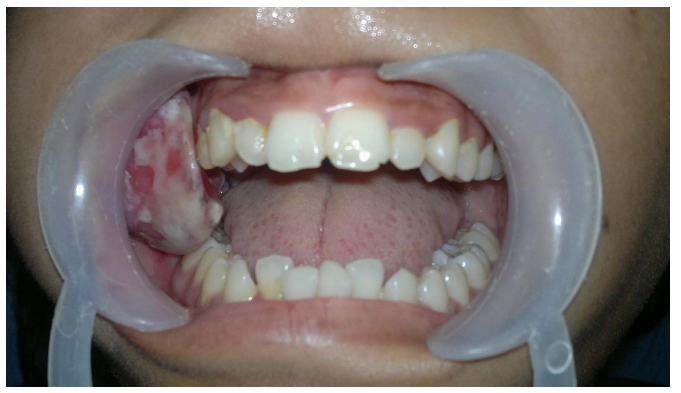

Figure 1 Intra-oral examination reveals a nodular and sessile mass in the right maxillary posterior tooth region.

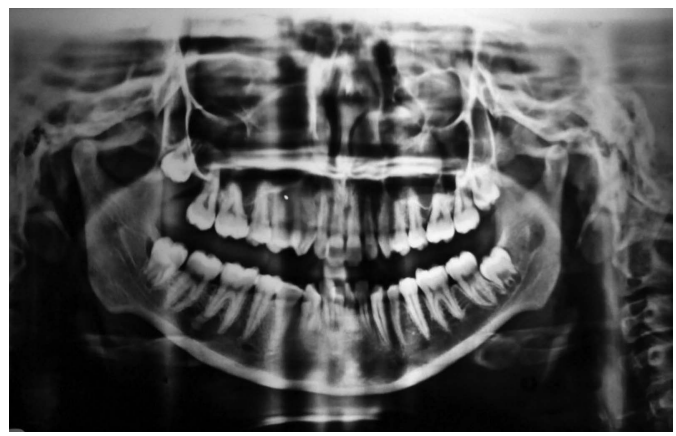

Figure 2 Radiographic investigation (orthopantomogram).

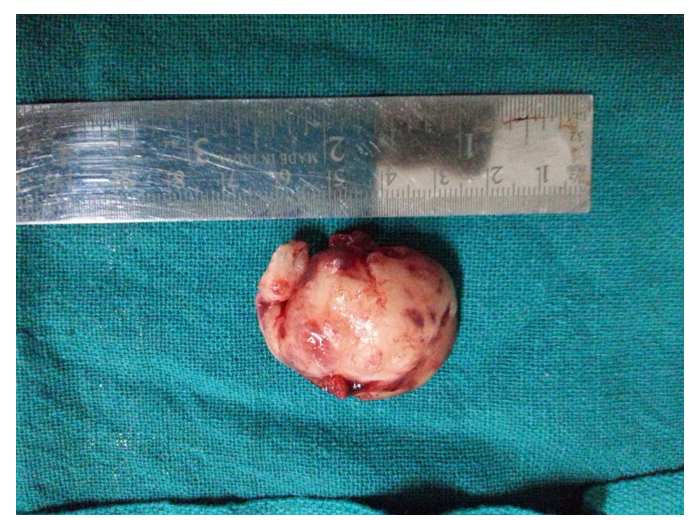

Figure 3 Excised lesion mass.

prescribed along with multivitamins. Later analysis of the specimen revealed a macroscopically smooth, well-circumscribed encapsulated lesion (figure 3). Histologically, fibroblast-like spindleshaped cells with a focally storiform and fascicular arrangement were seen. Non-mitotic figures, multinuclear giant cells, cell pleomorphism and nuclear atypia were visible. Polygonal, plump histiocytic cells were found among the spindle cells. The stroma was collagenised and inflammatory infiltrate was predominantly composed of plasma cells and lymphocytes (figure 4). Due to the varied microscopic appearance of the lesion, various differential diagnoses such as dermatofibroma and fibroxanthoma had been considered. However, based on the histopathological finding, a diagnosis of $\mathrm{BFH}$ was confirmed. The patient showed no recurrence of disease at 6-month follow-up (figure 5).

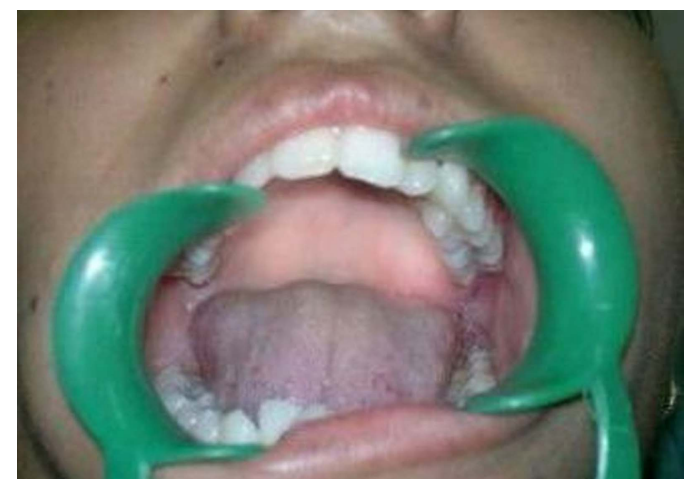

Figure 5 Patient at 6-month follow-up. 


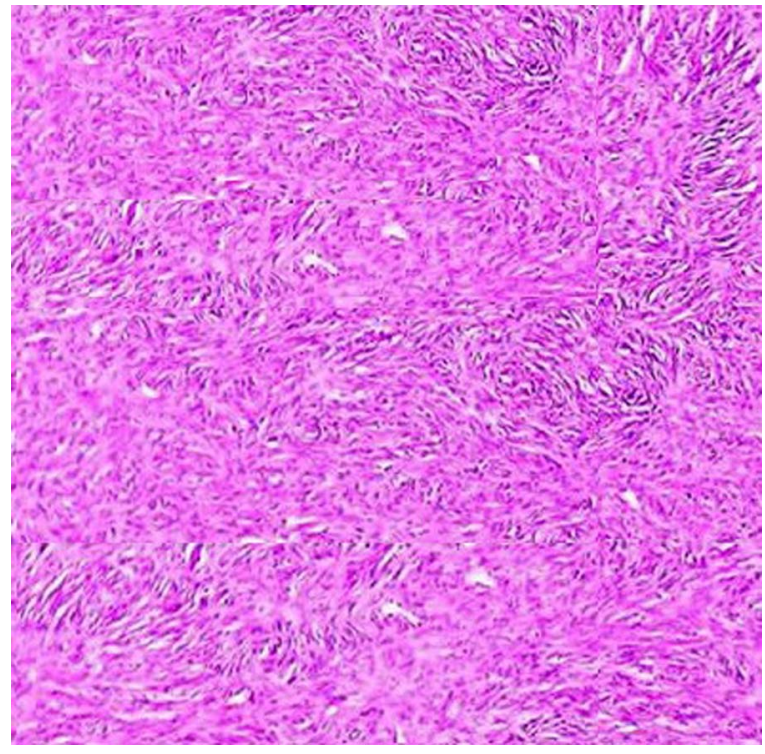

Figure 4 H\&E staining shows spindle-shaped cells in a storiform pattern.

\section{Learning points}

- The correct clinical examination and diagnosis of such lesions is challenging and usually based on a combination of light microscopy and immunohistochemistry.

- The rarity of benign fibrous histiocytoma makes it difficult for clinicians to distinguish it from other benign tumours.

- Differential diagnoses of other tumours more commonly found outside the head and region, especially deep soft tissue tumours, should be kept in mind.

Contributors All authors contributed equally to this case report.

Competing interests None.

Patient consent Obtained.

Provenance and peer review Not commissioned; externally peer reviewed.

\section{REFERENCES}

1 Skoulakis CE, Papadakis CE, Datseris GE, et al. Subcutaneous benign fibrous histiocytoma of the cheek. Case report and review of the literature. Acta Otorhinolaryngol Ital 2007;27:90-3.

2 Bielamowicz S, Dauer MS, Chang B, et al. Noncutaneous benign fibrous histiocytoma of the head and neck. Otolaryngol Head Neck Surg 1995;113:140-6.

Copyright 2014 BMJ Publishing Group. All rights reserved. For permission to reuse any of this content visit http://group.bmj.com/group/rights-licensing/permissions.

BMJ Case Report Fellows may re-use this article for personal use and teaching without any further permission.

Become a Fellow of BMJ Case Reports today and you can:

- Submit as many cases as you like

- Enjoy fast sympathetic peer review and rapid publication of accepted articles

- Access all the published articles

- Re-use any of the published material for personal use and teaching without further permission

For information on Institutional Fellowships contact consortiasales@bmjgroup.com

Visit casereports.bmj.com for more articles like this and to become a Fellow 